\title{
A STUDY OF KNOWLEDGE AND STIGMATIZING ATTITUDES OF ADOLESCENTS TOWARDS HIV/AIDS
}

\author{
Chinnatambi Narayanan Mohan Chandran', Maddi Prakash Kumar2, Duggirala Manikyamba3 , Amujuri Krishna Prasad 4 , \\ B. Rohit Kumar ${ }^{5}$ K. Adi Reddy ${ }^{6}$
}

${ }^{1}$ Associate Professor, Department of Paediatrics, Rangaraya Medical College, Kakinada. 2 Assistant Professor, Department of Paediatrics, Rangaraya Medical College, Kakinada. 3 Professor \& HOD, Department of Paediatrics, Rangaraya Medical College, Kakinada. ${ }^{4}$ Associate Professor, Department of Paediatrics, Rangaraya Medical College, Kakinada. 5Junior Resident, Department of Paediatrics, Rangaraya Medical College, Kakinada. 6Junior Resident, Department of Paediatrics, Rangaraya Medical College, Kakinada.

\begin{abstract}
Globally, almost a quarter of people living with Human Immunodeficiency Virus (HIV) are under the age of 25 years. ${ }^{1}$ In India, $35 \%$ of all reported AIDS cases are among the age group of 15-24 years indicating the vulnerability of the younger population to the epidemic. ${ }^{2}$ Andhra Pradesh is a high prevalence state for HIV patients with adult prevalence of $0.75 \%$ as opposed to national prevalence at $0.27 \% .^{3}$ East Godavari district is one among the high prevalence districts in the state of undivided Andhra Pradesh.4 The only treatment available is to delay the death of persons suffering from the disease. However, there is no cure. ${ }^{5}$ Thus it becomes necessary to educate young people, so that they can protect themselves from getting infected. This study was thus initiated to gauge the awareness about the dreaded disease among adolescents. Adolescence is shrouded with myths and misconceptions about sexual health and sexuality. This study tries to throw light onto the inadequacy of sex education at school level. The findings of the study would be helpful in implementation of future health education programmes.
\end{abstract}

\section{KEYWORDS}

HIV/AIDS Awareness, HIV/AIDS Knowledge, Adolescent Beliefs Towards HIV/AIDS, Stigmatizing Attitudes.

HOW TO CITE THIS ARTICLE: Chandran CNM, Kumar MP, Manikyamba M, et al. A study of knowledge and stigmatizing attitudes of adolescents towards HIV/AIDS. J. Evolution Med. Dent. Sci. 2016;5(12):485-490, DOI: 10.14260/jemds/2016/111

\section{INTRODUCTION}

\section{Study Method}

The study includes a total of 1722 students in the age group of 14-18 years from junior colleges in Kakinada, East Godavari District, Andhra Pradesh. Students were surveyed from two government and two private junior colleges using a predesigned questionnaire containing a total of 24 questions. This is a Community based cross-sectional observational study. The present study was carried out from September 2014 to August 2015.

\section{RESULTS}

- Out of 1722 students, 902 (52.38\%) were boys and 820 $(47.62 \%)$ were girls. Students were surveyed from two government and two private colleges. Government college students constitute 896 (52.04\%) and private college students $826(47.96 \%)$.

- In the present study, major source of information about HIV/AIDS for the first time was school (83.8\%). Parents and elders (7\%), friends (4.5\%), media (3.5\%). ${ }^{6}$ and health care professionals $(1.2 \%)$ were other sources of knowledge.

Financial or Other, Competing Interest: None.

Submission 22-12-2015, Peer Review 21-01-2016,

Acceptance 27-01-2016, Published 09-02-2016.

Corresponding Author:

Dr. K. Adi Reddy,

Junior Resident,

Department of Paediatrics,

Rangaraya Medical College, Kakinada.

E-mail: adi9949844121@gmail.com

DOI: $10.14260 / \mathrm{jemds} / 2016 / 111$
- Age at which students heard for the first time about HIV/AIDS was between 13-15 years in 1527 (88.6\%), 1012 years in $122(7 \%)$ and $>16$ years in $73(4.4 \%)$ students. ${ }^{7}$

- Out of 1722 students taken up for study 1270 students (73.7\%) knew the difference between HIV and AIDS as two separate entities; $61 \%$ of government college students and $87.6 \%$ of private college students knew the difference between HIV and AIDS. ${ }^{8}$

- In the present study, 1589 (92.2\%) of students knew blood transfusion as mode of transmission; $87.6 \%$ of students knew that HIV is transmitted from mother to child; $85 \%$ of students knew that HIV can be transmitted through sexual contact. 9 A $78 \%$ of students knew that HIV can be transmitted through sharing infected needles and razor blades; $63 \%$ of students knew that HIV can be transmitted through breastfeeding.

- The present study showed that $30.6 \%$ of respondents incorrectly stated that disease spreads through mosquito bite; $29.3 \%$ of students incorrectly are of the opinion. ${ }^{10}$ that disease is spread through usage of public toilets; $12.2 \%$ and $15.3 \%$ of students incorrectly feel disease is spread through sharing utensils and sitting on same bench with HIV patients respectively.

- In the present study, it was found that 1335 students (77.5\%) knew that avoiding multiple sexual partners is an effective preventive measure of HIV/AIDS; 79\%, 68.5\% and $65 \%$ students were aware of prevention of HIV by usage of condoms, screening blood before transfusion and treatment of HIV infected pregnant women respectively. ${ }^{11}$

- In the present study, it was found that $45.9 \%$ students feel HIV is punishment to people having multiple sexual partners; $37.8 \%$ of students feel that HIV is related to morality of people; $34 \%$ of students feel that HIV positive 
person should be quarantined from the society; $29 \%$ of students are of the view that HIV positive persons names should be made public. ${ }^{12}$

- 1174 (68\%) students among the surveyed are in favour of mandatory testing for HIV/AIDS before marriage.

- Regarding usefulness of sex education in curriculum 586 students felt it was very useful (34\%), 571(33\%) felt it was useful and 560 (33\%) were of the opinion that it was not useful.

\section{CONCLUSION}

In the study population major source of information about HIV/AIDS for the first time was school (83.8\%). Majority of students heard about HIV/AIDS for the first time at 13-15 years age. All the students have heard of HIV/AIDS, whereas only $73.7 \%$ knew the difference between HIV and AIDS; $68.9 \%$ correctly knew the full form of AIDS. Students had good knowledge about blood transfusion, infected needles, sexual contact and mother to child modes of transmission of HIV/AIDS. About $30.6 \%$ and $29.3 \%$ of students had misconception that HIV/AIDS can be transmitted through mosquito bite and usage of public toilets respectively.

Level of knowledge about HIV/AIDS transmission is higher among private college students and boys compared with government college students and girls respectively. Misconceptions about HIV/AIDS transmission are higher among girls and government college students. Knowledge levels among students about preventive strategies of HIV/AIDS is low compared with their knowledge about modes of transmission. In all aspects, level of knowledge is low particularly in government college girls. Stigmatizing attitudes towards PLWHA and HIV/AIDS were still higher among educated adolescents. More number of boys had stigmatizing attitude towards HIV/AIDS and PLWHA compared with girls. About $68 \%$ of students are in favours of mandatory testing for HIV/AIDS before marriage; $67 \%$ of students felt that sex education in the present form in the curriculum is useful in clearing their doubts.

\section{MATERIALS AND METHODS}

Design of the study - Community based cross-sectional observational study.

Period of study - One year from May 2013 to April 2014.

\section{Source of Data}

A total of 1722 students in the age group of 14-18 years from junior colleges in Kakinada, East Godavari District, Andhra Pradesh, were enrolled in the study. Students were surveyed from two government and two private junior colleges. Students willing for the survey were enrolled in the study.

\section{Method of collection of data}

Predesigned questionnaire containing a total of 24 questions were used for the study. These questions were designed to assess the knowledge of students on mode of transmission and prevention of HIV/AIDS, their attitude towards PLWHA. Opinion of students regarding sex education was also included in the questionnaire. Prior permission was taken from college authorities. The consent of the participants was taken initially explaining to them the purpose of the study. Students were assured about the confidentiality of their answers. They were not required to reveal their identity except for their gender. After data collection, any queries relating to HIV/AIDS that the participants had were answered. Data was tabulated and analysed.

\section{RESULTS}

A total of 1722 students were enrolled in this study. Observations and results are as follows.

\section{Demographic profile of study population}

\begin{tabular}{|c|c|c|c|}
\hline \multirow{2}{*}{ COLLEGE } & \multicolumn{2}{|c|}{ GENDER } & \multirow{2}{*}{ TOTAL } \\
\cline { 2 - 3 } & MALE & FEMALE & \\
\hline GOVERNMENT & 459 & 437 & $896(52.04 \%)$ \\
\hline PRIVATE & 443 & 383 & $826(47.96 \%)$ \\
\hline TOTAL & $902(52.38 \%)$ & $820(47.62 \%)$ & 1722 \\
\hline
\end{tabular}

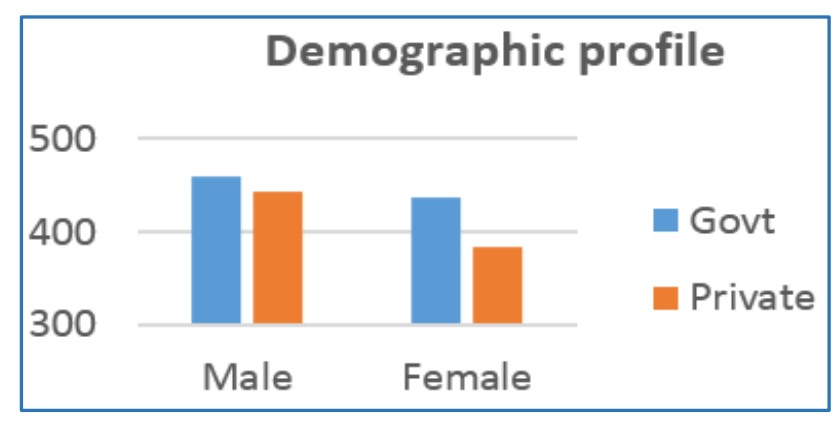

Out of 1722 students, 902 (52.38\%) were boys and 820 $(47.62 \%)$ were girls. Students were surveyed from two governments and two private colleges. Government college students constitute 896 (52.04\%) and private college students $826(47.96 \%)$.

\section{Source of Knowledge}

\begin{tabular}{|c|c|c|c|c|}
\hline \multirow{2}{*}{ SOURCE OF KNOWLEDGE } & \multicolumn{2}{|c|}{ COLLEGE } & \multicolumn{2}{c|}{ GENDER } \\
\cline { 2 - 5 } & GOVT & PRIVATE & BOYS & GIRLS \\
\hline FRIENDS & $31(3.4 \%)$ & $42(5 \%)$ & $31(3.4 \%)$ & $23(2.8 \%)$ \\
\hline SCHOOL & $722(80.6 \%)$ & $721(87.4 \%)$ & $775(86.5 \%)$ & $668(81.4 \%)$ \\
\hline PARENTS/ELDERS & $85(9.7 \%)$ & $36(4.4 \%)$ & $40(4.6 \%)$ & $81(10 \%)$ \\
\hline MEDIA & $38(4.4 \%)$ & $23(2.7 \%)$ & $20(2.7 \%)$ & $41(5 \%)$ \\
\hline HEALTHCARE PROFESSIONALS & $17(1.9 \%)$ & $4(0.5 \%)$ & $17(2.3 \%)$ & $7(0.8 \%)$ \\
\hline
\end{tabular}




\section{Source of konwledge}

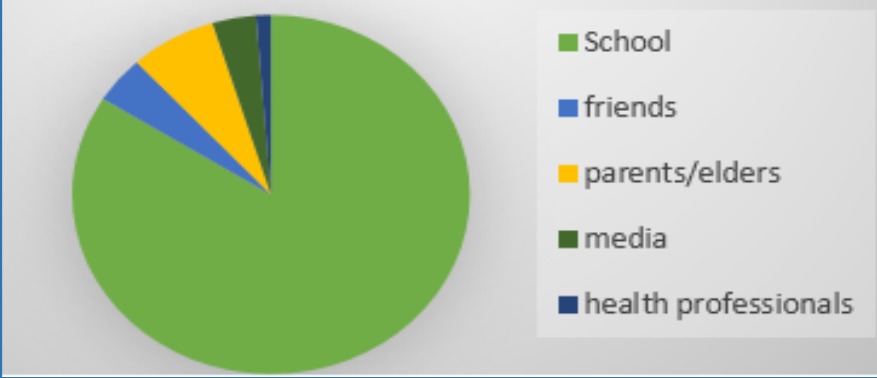

In the present study, major source of information about HIV/AIDS for the first time was school (83.8\%). Parents and elders (7\%), friends (4.5\%), media (3.5\%) and health care professionals (1.2\%) were other sources of knowledge.

3. Age at which students first heard about HIV/AIDS

\begin{tabular}{|c|c|c|c|c|}
\hline \multirow{2}{*}{ AGE (YR) } & \multicolumn{2}{|c|}{ COLLEGE } & \multicolumn{2}{c|}{ GENDER } \\
\cline { 2 - 4 } & GOVT & PVT & BOYS & GIRLS \\
\hline $10-12$ & $21(2.3 \%)$ & $101(12.2 \%)$ & $67(7.4 \%)$ & $55(6.7 \%)$ \\
\hline $13-15$ & $828(92.4 \%)$ & $699(84.6 \%)$ & $783(86.8 \%)$ & $744(90.8 \%)$ \\
\hline$>16$ & $47(5.3 \%)$ & $26(3.4 \%)$ & $52(5.8 \%)$ & $21(2.5 \%)$ \\
\hline
\end{tabular}

Age at which students heard for the first time about HIV/AIDS was between 13-15 years in 1527 (88.6\%), 10-12 years in 122 $(7 \%)$ and $>16$ years in $73(4.4 \%)$ students. Students from private colleges learnt about HIV/AIDS at an earlier age compared to government college students. No major difference was found between boys and girls in this regard.

\section{Knowledge about HIV/AIDS}

\begin{tabular}{|c|c|c|c|c|}
\hline \multirow{2}{*}{ KNOWLEDGE } & \multicolumn{2}{|c|}{ COLLEGE } & \multicolumn{2}{c|}{ GENDER } \\
\cline { 2 - 5 } & GOVT & PRIVATE & BOYS & GIRLS \\
\hline DIFFERENCE BETWEEN HIV \& AIDS & $546(60.9 \%)$ & $724(87.6 \%)$ & $749(83 \%)$ & $521(63.6 \%)$ \\
\hline FULLFORM OF AIDS & $519(57.9 \%)$ & $669(80.9 \%)$ & $695(77 \%)$ & $493(60 \%)$ \\
\hline TRANSMISSION BY HEALTHY LOOKING INDIVIDUAL & $410(45.7 \%)$ & $482(58.36 \%)$ & $490(54.3 \%)$ & $401(49 \%)$ \\
\hline
\end{tabular}

Out of 1722 students taken up for study, 1270 students (73.7\%) knew the difference between HIV and AIDS as two separate entities; $61 \%$ of government college students and $87.6 \%$ of private college students knew the difference between HIV and AIDS; 1188 (68.9\%) students correctly knew the full form of AIDS; 892 (51.8\%) students knew that a healthy looking individual can transmit HIV/AIDS. Private college students are more knowledgeable in this aspect than government college students.

\section{Knowledge about mode of transmission of HIV/AIDS}

\begin{tabular}{|c|c|c|c|c|}
\hline \multirow{2}{*}{ MODE OF TRANSMISSION } & \multicolumn{2}{|c|}{ COLLEGE } & \multicolumn{2}{|c|}{ GENDER } \\
\hline & GOVT & PRIVATE & BOYS & GIRLS \\
\hline HAVING SEXUAL CONTACT & $684(76.3 \%)$ & $780(94 \%)$ & $829(91.9 \%)$ & $635(77 \%)$ \\
\hline MOTHER TO CHILD IN PREGNANCY & $714(79.6 \%)$ & $795(96 \%)$ & $806(84 \%)$ & $703(85 \%)$ \\
\hline BREASTFEEDING BY MOTHER & $1124(50 \%)$ & $646(78 \%)$ & $635(67 \%)$ & $489(59.6 \%)$ \\
\hline SHARING INFECTED NEEDLES/RAZOR BLADES & $681(76 \%)$ & $677(81.9 \%)$ & $690(76 \%)$ & $668(81.4 \%)$ \\
\hline BLOOD TRANSFUSION & $798(89 \%)$ & $791(95 \%)$ & $843(93.4 \%)$ & $746(90.9 \%)$ \\
\hline
\end{tabular}

In the present study, 1589 (92.2\%) of students knew blood transfusion as mode of transmission; $87.6 \%$ of students knew that HIV is transmitted from mother to child; $85 \%$ of students knew that HIV can be transmitted through sexual contact; $78 \%$ of students knew that HIV can be transmitted through sharing infected needles and razor blades; $63 \%$ of students knew that HIV can be transmitted through breastfeeding.

Private college students were more knowledgeable than government college students regarding mode of transmission of HIV/AIDS. Comparison between boys and girls in this study, boys were more knowledgeable than girls about various modes of transmission except infected needles. Government college girls are less knowledgeable regarding modes of transmission of HIV/AIDS. 
6. Misconceptions regarding mode of Transmission of HIV/AIDS

\begin{tabular}{|c|c|c|c|c|}
\hline \multirow{2}{*}{ MODE OF TRANSMISSION } & \multicolumn{2}{|c|}{ COLLEG } & \multicolumn{2}{c|}{ GENDER } \\
\cline { 2 - 4 } & GOVT & PRIVATE & BOYS & GIRLS \\
\hline EATING FROM SAME CUPS/PLATES & $115(12.8 \%)$ & $96(11.6 \%)$ & $81(8.9 \%)$ & $130(15.8 \%)$ \\
\hline KISSING & $155(17.2 \%)$ & $135(16.3 \%)$ & $116(12.8 \%)$ & $174(21.2 \%)$ \\
\hline SITTING ON SAME BENCH WITH HIV/AIDS PATIENT & $186(20.7 \%)$ & $79(9.5 \%)$ & $81(8.9 \%)$ & $184(22.4 \%)$ \\
\hline USING PUBLIC TOILETS & $323(36 \%)$ & $182(22 \%)$ & $185(20.5 \%)$ & $320(39 \%)$ \\
\hline MOSQUITO BITE & $359(40 \%)$ & $168(20.3 \%)$ & $231(25.6 \%)$ & $296(36 \%)$ \\
\hline
\end{tabular}

The present study showed that $30.6 \%$ of respondents incorrectly stated that disease spreads through mosquito bite; $29.3 \%$ of students incorrectly are of the opinion 10 that disease is spread through usage of public toilets; $12.2 \%$ and $15.3 \%$ of students incorrectly feel disease is spread through sharing utensils and sitting on same bench with HIV patients respectively.

Government college students had more misconceptions than private college regarding mode of transmission of HIV/AIDS. Girls had more misconceptions than boys regarding mode of transmission of HIV. Government college girls had more misconceptions about HIV/AIDS transmission.

\section{Knowledge regarding prevention of HIV/AIDS}

\begin{tabular}{|c|c|c|c|c|}
\hline \multirow{2}{*}{ PREVENTIVE MEASURE } & \multicolumn{2}{|c|}{ COLLEGE } & \multicolumn{2}{c|}{ GENDER } \\
\cline { 2 - 5 } & GOVT & PRIVATE & BOYS & GIRLS \\
\hline AVOIDING MULTIPLE SEXUAL PARTNERS & $585(65 \%)$ & $750(90 \%)$ & $743(82 \%)$ & $592(72 \%)$ \\
\hline USAGE OF CONDOM & $629(70 \%)$ & $737(89 \%)$ & $770(85 \%)$ & $596(72 \%)$ \\
\hline SCREENING OF BLOOD & $551(61.4 \%)$ & $627(75.9 \%)$ & $770(85.3 \%)$ & $553(67.4 \%)$ \\
\hline SCREENING/TREATING PREGNANT WOMEN & $522(58.2 \%)$ & $598(72.3 \%)$ & $662(77.3 \%)$ & $480(58 \%)$ \\
\hline
\end{tabular}

In the present study, it was found that 1335 students (77.5\%) knew that avoiding multiple sexual partners is an effective preventive measure of HIV/AIDS; 79\%, 68.5\% and 65\% students were aware of prevention of HIV by usage of condoms, screening blood before transfusion and treatment of HIV infected pregnant women respectively.

Private college students had better knowledge regarding preventive measures in comparison to their government counterparts. Boys were more knowledgeable compared to girls regarding knowledge on preventive measures of HIV/AIDS.

\section{Attitude towards HIV/AIDS and PLHA: Stigmatizing Attitudes}

\begin{tabular}{|c|c|c|c|c|}
\hline \multirow{2}{*}{ STIGMATIZING ATTITUDES } & \multicolumn{2}{|c|}{ COLLEGE } & \multicolumn{2}{c|}{ GENDER } \\
\cline { 2 - 5 } & BOYS & GIRLS & BOYS & GIRLS \\
\hline $\begin{array}{c}\text { HIV IS PUNISHMENT TO PEOPLE HAVING } \\
\text { MULTIPLE SEXUAL PARTNERS }\end{array}$ & $342(38 \%)$ & $450(54 \%)$ & \multirow{2}{*}{$437(48 \%)$} & $355(43.2 \%)$ \\
\hline IT IS RELATED TO MORALITY & $293(32.7 \%)$ & $358(43 \%)$ & $375(41.5 \%)$ & $276(33.6 \%)$ \\
\hline HIV PATIENTS SHOULD BE QUARANTINED & $338(37.7 \%)$ & $252(30.5 \%)$ & $300(33.2 \%)$ & $290(35.3 \%)$ \\
\hline HIV PATIENT'S NAMES BE MADE PUBLIC & $369(41.1 \%)$ & $129(15.6 \%)$ & $290(32.2 \%)$ & $208(25.3 \%)$ \\
\hline
\end{tabular}

In the present study it was found that $45.9 \%$ students feel HIV is punishment to people having multiple sexual partners; $37.8 \%$ of students feel that HIV is related to morality of people; $34 \%$ of students feel that HIV positive person should be quarantined from the society; $29 \%$ of students are of the view that HIV positive person's names should be made public. More number of boys had stigmatizing attitude towards PLWHA compared to girls.

\section{Attitude regarding preventive measures of HIV/AIDS}

\begin{tabular}{|c|c|c|c|c|}
\hline \multirow{2}{*}{ OPINION } & \multicolumn{2}{|c|}{ COLLEGE } & \multicolumn{2}{c|}{ GENDER } \\
\cline { 2 - 5 } & GOVT & PVT & BOYS & GIRLS \\
\hline MANDATORY TESTING BEFORE MARRIAGE & $537(60 \%)$ & $637(77 \%)$ & $564(62.5 \%)$ & $610(74.3 \%)$ \\
\hline HAVE YOU SEEN A CONDOM & $393(43.8 \%)$ & $245(30 \%)$ & $318(38 \%)$ & $320(39 \%)$ \\
\hline
\end{tabular}

$1174(68 \%)$ students among the surveyed are in favour of mandatory testing for HIV/AIDS before marriage. Private college students in higher proportion (77.1\%) are in favour of mandatory testing before marriage compared to their government counterparts (60\%). Girls (74.3\%) in higher proportion were in unison for mandatory testing for HIV before marriage compared to boys $(62.5 \%)$. 
10. Opinion of Students on Sex Education

\begin{tabular}{|c|c|c|c|c|}
\hline \multirow{2}{*}{ OPINION } & \multicolumn{2}{|c|}{ COLLEGE } & \multicolumn{2}{c|}{ GENDER } \\
\cline { 2 - 5 } & GOVT & PRIVATE & BOYS & GIRLS \\
\hline VERY USEFUL & $370(41 \%)$ & $216(35 \%)$ & $325(36 \%)$ & $341(32 \%)$ \\
\hline USEFUL & $322(36 \%)$ & $249(34 \%)$ & $298(33 \%)$ & $213(42 \%)$ \\
\hline NOT USEFUL & $204(23 \%)$ & $256(31 \%)$ & $280(31 \%)$ & $2(26 \%)$ \\
\hline
\end{tabular}

Regarding usefulness of sex education in curriculum, 586 students felt it was very useful (34\%), 571 (33\%) felt it was useful and $560(33 \%)$ were of the opinion that it was not useful.

\section{DISCUSSION}

In this study, 1722 students from urban area of Kakinada town in East Godavari District, Andhra Pradesh, were enrolled from both government and private junior colleges studying $11^{\text {th }}$ and $12^{\text {th }}$ classes. It is a comparative study, helps to bring out the difference in knowledge among students. Private college students due to their effluent familial and educated parental background are more knowledgeable about HIV/AIDS. Private college students are having more exposure to media (internet/TV) in comparison with government college students.

In this study, students heard about HIV/AIDS for the first time from school point to the fact that students had first learnt about HIV/AIDS from lessons in their general science text books in their curriculum in $10^{\text {th }}$ standard. In the present study, students learnt about HIV/AIDS for the first time at the age of 15 years in $43.2 \%, 14$ years in $31.1 \%$ and 13 years in $14.3 \%$. This points to the fact that first knowledge about HIV/AIDS was through their curriculum in $10^{\text {th }}$ class. In this study, $1270(73.7 \%)$ students were aware that HIV and AIDS are not synonymous; $77 \%$ of boys knew the full form of AIDS correctly compared with $60 \%$ of girls. This may be due to more exposure of boys to social networks and may also reflect inhibition among girls to discuss such issues with friends and others. Girls may have a barrier of shyness between them and information providers.

In this study, knowledge of study population regarding sexual contact as a mode of transmission of HIV/AIDS was found to be $85 \%$. Considering the age group of the study subjects in the present study who are most vulnerable to drug abuse, awareness campaigns and mass education about AIDS, safe blood transfusion and safe injection practices is the need of the hour. These programs could protect the vulnerable sections of the society from the dreaded disease.

In this study, various misconceptions about transmission of HIV/AIDS existed among the study population. Mosquito bite was thought as a mode of transmission in $30.6 \%$ and students also consider casual contact like sitting with HIV positive person, sharing food with them as a mode of transmission. It was observed that a good number of youths were aware of modes of transmission of HIV/AIDS and its prevention, but there were misconceptions among them as well. Removal of such misconceptions among youth is very important or else it can create a phobia among the masses.

In this study, knowledge of students regarding various preventive measures was found to be deficient. Avoiding multiple sexual partners was believed as a preventive measure by $77.5 \%$ of students in present study, also $79 \%$ of study population knew that usage of condom can prevent HIV transmission. ${ }^{13}$ Youth displayed less awareness of preventive methods in comparison to awareness of transmission modes of the disease. Though knowledge of adolescents regarding transmission of HIV/AIDS is satisfactory, their knowledge about prevention is relatively poor. ${ }^{14}$ This signifies the importance of emphasis on preventive measures, while educating adolescents about HIV/AIDS. Education and correct scientific information are urgently needed to adolescent boys and girls to avoid myths and misconceptions on HIV and AIDS. This knowledge enables them to take rational decisions regarding their sexual life and how they can protect themselves against HIV infection.

In this study, $45.9 \%$ of study population believed that HIV is punishment by GOD to people having multiple sexual partners. Private college student's attitude was more positive towards HIV positive persons. Government college students in view of coming from lower strata of society had various misbeliefs, which got reflected in their attitude towards HIV/AIDS and PLWHA.

In this study, $68 \%$ of students were in favour of mandatory testing of couples prior to marriage. Government college students in lesser proportion (60\%) compared to private college students $(77 \%)$ were supporting mandatory testing for HIV prior to marriage. Girls (74.3\%) in higher proportion than boys $(62.5 \%)$ were in favour of mandatory testing of HIV prior to marriage. These results show that girls were more apprehensive about their partner's status compared to boys.

In this study, students in almost equal proportions were of the opinion about usefulness of sex education in their curriculum; $34 \%$ of students think sex education in the present form in their curriculum is very useful; $33 \%$ feel it is useful and $33 \%$ feel it is not useful in clearing their doubts.

\section{CONCLUSION}

Results of this study showed that introduction of reproductive health and HIV/AIDS in the curriculum in formal education is not imparting complete knowledge. Teachers may have delicate issues to interact with students regarding sex education and talking about HIV. It is imperative to utilize highly trained and motivated outreach workers from NGOs and voluntary organizations for purpose of sex education in schools. Results of this study reveal that socio economic status, education standards and gender as predictors of awareness about HIV/AIDS. ${ }^{15,16}$ The present study was a survey at one period in time, so it has the limitations of a cross-sectional study. However, the findings are very relevant to adolescents in the college going age group. The study findings stress on the need of a clearly formulated adolescent health education and AIDS awareness programs targeted at school and college students. 


\section{REFERENCES}

1. UNAIDS Inter-agency Task Team on HIV and Young People (2004) At the Crossroads: Accelerating Youth Access to HIV/AIDS Interventions UNAIDS. New York.

2. National AIDS Control Organization (2005). India Resolves to Defeat HIV/AIDS. Ministry of Health and Family Welfare, Government of India. New Delhi.

3. http://naco.gov.in/upload/2014/mslns/State/Fact/ Sheet/2013-14.pdf.

4. Facts, Figures and Response to HIV/AIDS in Andhra Pradesh.

Internet:file:///H:/FactsFiguresResponse_HIVAIDS_And raPradesh.pdf.

5. Pence GE (2008). Preventing the Global Spread of AIDS. In Medical Ethics Accounts of the Cases that Shaped and Define Medical Ethics (p. 330). New York: McGraw-Hill.

6. Yadav et al. Awareness of HIV/AIDS among rural youth in India: a community based cross-sectional study. J Infect Dev Ctries 2011;5(10):711-716.

7. Bhatia V, Puri S, Mangat C, et al. An intervention study to enhance AIDS awareness among underprivileged population in Chandigarh. The Internet Journal of Health [Internet] 2010;11(1).

8. Anjali Singh and Shikha Jain: Awareness of HIV/AIDS among school adolescents in Banaskantha District of Gujarat. Health and Population: Perspectives and Issues, Vol. 32(2), 59-65, 2009.

9. National Behavioural Surveillance Survey-General population. National AIDS Control Organization, Ministry of Health and Family Welfare, Government of India. 2006:36. Page no. 32, 42-46, 50, 108.
10. Garg N, Singh SP and Mishra RN (2005): Knowledge of first-year graduate students about HIV/AIDS and its socio-demographic correlates in Varanasi; Indian Journal of Prev Soc Medi, 36 (3\&4), p 132-136.

11. Government of India. District Level Household Survey 2. Ministry of Health and Family Welfare, New Delhi 20022004.

12. Vaz FS, Ferreira AMA, Motoghare DD, et al. (2005): Discriminatory attitudes of a rural community towards people with HIV/AIDS: experience from Goa; Ind Jour of Comm Med Vol 30(2).

13. Malleshappa K, Shivaram Krishna, Shashikumar. Awareness and attitude of youth toward HIV/AIDS in rural Southern India. Biomedical Research 2012;23(2):241-246.

14. Gaash B, Ahmad M, Kasur R, et al. (2003). Knowledge, attitude and belief on HIV/AIDS among the female senior secondary students in Srinagar District of Kashmir. Health Popul Perspect Issues 26:101-109.

15. National Family Health Survey (NFHS-3) 2005-06. International Institute for Population Sciences (IIPS) and Macro International. Mumbai: India. 2007; Volume I, Chapter 11:333.

16. Agarwal RM and Rous JJ (2006). Awareness and quality of knowledge regarding HIV/AIDS among women. J Dev Stud 42:371-401. 